\title{
Rules, indications and documentation for applying physical coercion by emergency medical services
}

\begin{abstract}
Helping people with mental disorders poses a challenge to the members of medical emergency services (EMS). Psychiatric patients are often unpredictable and applying physical coercion is necessary in some cases.

The aim of this paper was to present and comment on legal foundations of application of different forms of physical coercion by EMS members and describe how to fill out medical records required every time physical coercion was used.

According to the amendments of Polish Mental Health Act made in 2010, the EMS members were granted the right to apply physical coercion. Further amendments to the Mental Health Act and the introduction of appropriate Ministry of Health decree define forms of physical coercion, indications to apply physical coercion and include a sample of proper medical records which are required in all cases of application of physical coercion.

Application of physical coercion should always be treated as last-line treatment option while helping patients suffering from mental disturbances. Obeying the law every time a decision regarding physical coercion is made protects patients' right to receive dignified care and treatment as well as the rights of medical professionals.
\end{abstract}

Keywords: physical coercion, EMS, paramedic, psychiatric disorders.

DOI: $10.1515 /$ pjph-2015-0029

\section{INTRODUCTION}

On $15^{\text {th }}$ April 2011, the Polish Parliament passed the Act on Medical Activity. Its introduction caused multiple changes in the regulations regarding medical services offered to patients [1]. The amendments made to the article 18 of 1994 Mental Health Act (MHA) regarded the regulations of applying physical coercion [2]. Based on regulations presented in Act on Medical Activity released by Polish Ministry of Health on $28^{\text {th }}$ June 2012, a new decree describing the application of physical coercion in a detailed way. The text included information on keeping proper medical records required in those cases. The decree provides for the use of physical coercion not only in psychiatric hospitals or nursing homes but in every hospital department, in private practice, group private practice, specialist medical practice and group specialist medical practice as well [3]. Furthermore, physical coercion might be applied by members of emergency medical services (EMS) while providing rescue operations, regardless of whether it is a basic or a specialist EMS team. Some appropriate law regulations were introduced in 2010 when the Polish Parliament passed amendments to the 1994 (MHA) [2]. The authors of this study present the current legal regulations, discuss indications to physical coercion applications by EMS members emphasizing needs for keeping proper medical records required in such cases.

\section{Basic definitions}

According to legal literature, physical coercion is a "limitation of patient's movement or his immobilization by means of physical force, mechanical restraints or other means in order to provide safety for patients and his surroundings and to perform medical and nursing procedures" [4].

Taking the medical point of view, physical coercion should be regarded as a therapeutic intervention which aims at enabling the patient regain self-control within a certain time span [5]. It goes without saying that applying physical coercion is a procedure that limits the patient's personal and physical immunity. Thus, such violation of personal freedom by any of available and defined by the law means of physical coercion is an ultimate action and should be applied only in situations when it's unavoidable and other forms of actions which aim was to provide safety for patient and his surroundings failed. Every step of physical coercion procedure should involve law obedience and respect dignity of a patient in order to prevent transformation of physical coercion into physical violence [6].

${ }^{1}$ Department and Faculty of Trauma Surgery and Emergency Medicine at Medical University of Lublin, Poland
${ }^{2}$ UMCS Lublin Faculty of Emotional and Cognitive Psychology, Poland 


\section{Legal basis of physical coercion}

The article 3 paragrapg 6 of 1994 MHA describes the forms of physical coercion allowed in Poland. These are the following forms:

a) apprehension, i.e. ad hoc, short term immobilization of a person by means of physical force;

b) forced medical treatment, i.e. either ad hoc or previously scheduled introduction of medications into patients body without their consent;

c) immobilization, i.e. suppression of a patient with use of belts, holders, sheets, straitjackets or other types of technical devices;

d) isolation, i.e. placing a patient in a closed and accurately equipped single room [2].

For obvious reasons, EMS members are not able to isolate their patients. Hence, in the following parts of this paper, the authors paid attention to the first three forms of physical coercion.

Literature data and authors' own experience show that apprehension is most commonly used in order to prevent patients from escaping a psychiatric hospital or nursing home and to control aggression of a patient toward other people or objects in his surroundings. This form of physical coercion is also used while shepherding patients from their homes to an ambulance and from an emergency room to specific ward in hospital. It could also be used when trying to encourage patients to follow personal hygiene standards. In case of this and other types of physical coercion, the use of physical force should be absolute essentials. It must not lead to any physical violence against patients. However, paramedics using this procedure may apply defensive and incapacitating moves as well as other self-defense techniques [6,7]. It is worth noticing that holding a child in order to perform diagnostic or therapeutic procedures should not be treated as a form of physical coercion [8].

Forced medical treatment either ad hoc or previously scheduled in EMS is usually limited to tranquilizers. Benzodiazepines and neuroleptics are on top the list of the most commonly used ones. Applying such medication might lead to serious side effects. Using benzodiazepines intravenously can lead to apnea and, in some cases, after a first dose of benzodiazepine a paradoxical reaction may develop - it is a situation when patients become even more agitated than before receiving the medication [9]. Neuroleptics, especially potent neuroleptics such as haloperidol, may cause acute dyskinesia, particularly when given to young males $[6,9,10]$.

Immobilization, which is a suppression of a patient with use of belts, holders, sheets, straitjackets or other types of technical devices (e.g. handcuffs, ) is a form of physical coercion limiting patients' freedom in the most extensive way. As a result, such decisions are particularly hard to make. Long-term immobilization, according to Ministry of Health decree is allowed in psychiatric hospitals only. In such situations, immobilization belts (both secured with buckles and secured with magnetic keys) and holders are advised. If such devices are not available, properly prepared sheets may be used instead. Straitjackets are not advised for longterm immobilization mainly due to high risk for suffocation. However, they can be used by EMS members to immobilize the patient and transport them to the nearest psychiatric hospital $[2,5]$.
Article 3 of 1994 MHA also provides a legal definition of a mentally disturbed patient. According to this article a mentally disturbed patient may be either:

a) a mentally ill person (presenting psychotic disorders);

b) a mentally handicapped person;

c) a person who presents other disturbances which according to medical knowledge are mentally based and such person requires medical treatment or other forms of help and care indispensable for life in family of community [2].

Directions to apply physical coercion are described in article 18 of 1994 MHA. The article states that physical coercion may be applied to a mentally disturbed patient if an appropriate MHA article allows for this. The following are other conditions for the use of physical coercion:

1. patient makes an assassination attempt on

a) their life or health or life or health of others, or

b) public safety

2. patient violently demolishes or damages objects in their surroundings, or

3. severely hampers or prevents the functioning of psychiatric healthcare entity or nursing home [2].

It is essential to remember that EMS member applying physical coercion in different situations can be subject to criminal responsibility. Physical coercion should not be used against patients whose aggressive behavior is not caused by mental disturbances or those who are unable to make conscious and unrestricted decisions. Application of physical coercion in such cases is a ground to press charges against an EMS member. These may include: treatment without consent, violation of personal immunity, constraint of a person or disturbance of the functioning of a bodily organ or health disturbance [11,12]. According to Krakowska, applying physical coercion against individuals suffering from a medical condition and being, thus, unable to make conscious and unrestricted decisions, is possible with substitute consent only [13].

In cases described in points 1 and 2 of article 18 of 1994 MHA application of all four forms of physical coercion is allowed and in cases described in point 3 i.e. if patient severely hamper or make impossible functioning of psychiatric healthcare entity or nursing home only apprehension or forced medical treatment are allowed [2].

A patient's assassination attempt on their own life or health is usually a very violent and radical action. Patients may try to commit suicide (e.g. through medication overdose, wrist cutting or hanging), perform an act of self-injury or present violent psychomotor agitation which may lead to fatal emaciation (e.g. acute delirium states medically and mentally based, maniac states, psychotic depression states with psychomotor agitation or stupor, catatonic states with psychomotor agitation or stupor and agitation in patients after brain trauma). Also, using psychoactive substances such as designer drugs, hallucinogens, alcohol or other substances which cause toxic damage to the brain poses real threat to someone's life or health $[2,11]$.

Patient's assassination attempt on life or health of other people happens when the patient becomes aggressive towards family members or bystanders. It may take the form of active physical aggression (e.g. beating), preparation 
for an aggressive attack (e.g. collecting and carrying knives and guns) or verbal aggression. Such behaviors are observed in patients suffering from delusional syndromes, mainly delusion of persecution, and catatonic syndromes $[11,12]$.

Posing a threat to public safety relates to situations when patient's behavior may lead to serious danger to life or health of many people or some property of considerable size. It does not have to be an act of aggression while taking the form of putting objects on fire. Other situations of that sort are described in Penal Code and they include: building collapse, explosions, dispersion of hazardous substances and violent liberation of nuclear energy or nuclear radiation [12].

Violent demolition or damaging objects in patient's surroundings is another indication for physical coercion. Such situations are usually connected to emotional agitation which presents itself as aggressive behavior. This aggression is usually directed toward objects in patient's surroundings and patient's behavior is usually so disorganized that it is impossible to predict their movements and actions. Patient cannot control their actions and behavior which poses a threat to their surroundings. They might be throwing objects such as a pillow, which may seem as not very threatening, however, there is no guarantee that the next object may be something much more dangerous, e.g. a TV set or a knife lying on a table [11].

For obvious reasons, EMS members do not apply physical coercion in cases of patients who severely hamper or make the functioning of psychiatric healthcare entity or nursing home impossible.

Application of physical coercion by EMS members is not limited to situations described in article 18 of 1994 MHA. Article 21 of 1994 MHA states that physical coercion may by applied in case of a person whose behavior, due to mental disturbances, poses direct threat to his own life or life or health of others or such a person is unable to cater needs, does not give permission to perform psychiatric examination and should be transferred to psychiatric hospital for such a examination. This person should be transferred to a psychiatric hospital in presence of a physician, nurse or EMS members with application of physical coercion if necessary [2].

EMS members are allowed to apply physical coercion in cases of transporting patients with mental health problems to psychiatric hospitals, particularly when the admission was granted by an appropriate court order. In such cases, there is no need to obtain a patient's written consent [2].

They are also allowed to use physical coercion, as a means of executing a court order of placing a mentally il or handicapped patients in a mental institution. This procedure is applied especially when other care resources are unavailable and patient requires care and nursing whilst not requiring hospitalization and having denied to be placed in nursing home [2].

In such cases, the execution of the court order is performed by police officers, assisted by a physician, nurse or EMS members. They are allowed to apply physical coercion if necessary (article 46 of 1994 MHA) [2].

\section{Proper keeping of medical records in case of physical coercion}

Until the 2010 amendment of 1994 MHA the decision to apply physical coercion was made by a physician. They chose the appropriate form of coercion and supervised the whole procedure. Should special circumstances arise, a nurse working in psychiatric hospital or nursing home is allowed to make a decision regarding physical coercion. The 2010 amendment allows more people to make such decisions. According to the current regulations, the decision to apply physical coercion can also be made by members of emergency medical services (EMS) while providing rescue operations and dispatcher has to be notified about this decision immediately after it was made. Not every member of EMS team is allowed to make such a decision. Only person who is really in charge of providing rescue operations is allowed to do that. Paramedics can make such a decision if it is impossible to obtain physician's decision in this matter [12]. In such cases physical coercion last until a physician is available and if it is impossible only during transportation of such a patient to psychiatric hospital or hospital indicated by dispatcher. Before a decision of application of physical coercion is made person who actually makes this decision is obliged to inform patient about possible application of physical coercion and such a decision should be noted both in individual and collective medical records $[2,3]$.

A form of physical coercion should be as little strenuous as possible for the patient and in every case patients needs should regarded as special and procedure should be performed with special precaution [2].

While applying physical coercion physician, nurse or person in charge of providing rescue operations can receive additional assistance, on request, from other EMS teams, police and fire department [2]. Especially basic EMS teams when staffed mainly with women may require additional assistance from other EMS teams, police and fire department [2].

Every case of application of physical coercion by EMS team members is legitimized by a psychiatrist licensed by marshal of the appropriate voivodship. Such a legitimization should be done within 3 days from day of procedure [2].

Based on amendments to 1994 MHA regulations Ministry of Health on $28^{\text {th }}$ June 2012 introduced decree describing detailed ways of physical coercion application and keeping proper medical records required in those cases [3].

The decree states that application of one form of physical coercion described above does not end the whole procedure. This means, different forms may be applied at the same time or consecutively. For instance, patient may be apprehended, then medicated with use of physical force and, if previous methods did not have awaited results, immobilized with usage of available equipment [3].

Physical coercion should be ended as soon as the reason for its application are no longer persent [3].

Physical coercion should be applied only by previously trained staff members. In case of EMS members, the EMS administrator is responsible for providing such training [3].

Proper protection of a person in whom physical coercion was applied involves removal of all potentially dangerous objects, especially sharp objects, glasses, dental plates, belts, shoelaces and sources of fire [3].

If physical coercion was applied during rescue operations, the person who made such a decision is obliged to inform a physician from hospital to which patient was transported about reasons for physical coercion, form of physical coercion and time of whole procedure. The person 
in charge of providing rescue operations should also hand over the first page of appropriate notification [3].

If the patient was immobilized, the person in charge of providing rescue operations should also put down the reasons for, form of physical coercion and time of procedure on appropriate notification which is presented as addendum 3 to Ministry of Health decree [3].

The above mentioned notification contains the following information: EMS administrator ID, operation ID, age of patient, type of EMS (Specialist/Basic), patient's gender and date of operation. Furthermore, such information should be noted: patient's name and last name, ID stamp of hospital to which patient was transported, time of arrival to this hospital and duration of physical coercion [3].

Moreover, the document should list the reasons for physical coercion, exact time of physical coercion application and a confirmation that the dispatcher was notified about physical coercion [3].

The next part of the document contains detailed information regarding EMS team members (names and last names) who applied physical coercion are required [3].

The following part of notification points that members of the basic EMS team are allowed to apply physical coercion in a form of apprehension or immobilization with belts, holders, sheets, straitjackets or other types of technical devices. Members of specialist EMS team which involve a physician are allowed to apply physical coercion in a form of apprehension, forced medical treatment (either ad hoc or previously scheduled) or immobilization [3].

Next section of notification allows EMS team members to describe how patient is behave while being under physical coercion, especially while being immobilized. One or more of following options should be marked: struggle, shout, calm, cry, laugh, sing, mumble, without psychiatric disorders, fluids infusion, defecate, urinate, short-time release, other [3]. Status of a patient who is immobilized should be checked not less than every 15 minutes, which is especially important when distance between EMS team intervention site and psychiatric hospital is considerable. While checking patients status it is mandatory to check immobilization correctness, whether belts or other devices are too tight, too loose and if patient suffered any trauma during procedure [3].

A properly filled documentation contains the following information: whether the patient was transposed by EMS team or whether they had been informed about possibility of application of physical coercion [3].

Information regarding if, and if yes in which way, physical coercion had an influence on patient's health should be written in next part of notification and in here involvement of other EMS team, police or fire department during procedure should be marked [3].

Next section of notification is intended to present possible notices regarding procedure (it is a place where details regarding possible trauma of a patient during procedure may be put) and five last sections are for remarks and signatures of person who made a decision of application of physical coercion, followed by remarks and signatures of EMS administrator and by remarks and signatures of a psychiatrist licensed by marshal of the appropriate voivodship who legitimize procedure [3].

\section{CONCLUSION}

The application of physical coercion should always be regarded as last choice in broad array of possible management options of patients with psychiatric disorders. The forms of physical coercion allowed by the Polish law tend to limit patient's freedom. However, it is important to remember that a decision about applying physical coercion is made in situations when a patient poses a threat to himself or people in his surroundings, like EMS members trying to help. Application of physical coercion while taking appropriate laws into consideration is a protection for both patient's rights to dignified care and treatment and rights of people trying to help this patient. It seems, that obeying the law minimize possible side effects of physical coercion. The time which passed from introduction of new decree regulating application of physical coercion is too short to assess it. It is however, worth mentioning that introduction of this law increased legal protection of EMS teams members. We hope that the article allowed readers to better understand reasons for application of physical coercion and offered guidelines regarding proper keeping of medical records required in such situations. Further analysis of EMS interventions involving application of physical coercion and circumstances in which this procedure was introduced may help specify, improve and complement appropriate laws.

\section{REFERENCES:}

1. Ustawa z dnia 15 kwietnia 2011 r. o działalności leczniczej (Dz.U. 2011 $\mathrm{Nr} 112$ poz. 654).

2. Ustawa z dnia 19 sierpnia 1994 r. o ochronie zdrowia psychicznego (tekst jedn. Dz.U. z 2011 r. Nr 231, poz. 1375, z późń. zm.).

3. Rozporządzenie Ministra Zdrowia z dnia 28 czerwca 2012 r. w sprawie sposobu stosowania i dokumentowania zastosowania przymusu bezpośredniego oraz dokonywania oceny zasadności jego zastosowania (Dz.U. 2012 nr 0 poz. 740).

4. Milik A. Przymus bezpośredni w psychiatrii w świetle obowiązujących przepisów. PiM. 2007;2.

5. Kokoszka A. Postępowanie w stanach naglących. In A. Bilikiewicz, S. Pużyński, J. Rybakowski, J. Wciórka. Psychiatria. Wrocław: Urban\&Partner; 2003. p. 321-3.

6. Kupś I, Pełka-Wysiecka J, Samochowiec J. Przymus bezpośredni - realizacja założeń Ustawy o ochronie zdrowia psychicznego wobec pacjenta zachowującego się agresywnie w wybranych placówkach służby zdrowia w województwie zachodnio-pomorskim. Psychiatr. 2007;3(4):87-96.

7. Dąbrowski S. Przymus bezpośredni stosowany w niektórych czynnościach leczniczych. Psychiatr Pol. 2002;2:193-200.

8. Adamkiewicz-Herok B, Madowicz J. Przymus bezpośredni w ratownictwie medycznym. Na ratunek. 2013;1(6):57-61.

9. Petit JR. Psychiatria ratunkowa. Wrocław: Urban\&Partner; 2007.

10. Bilikiewicz A, Pużyński S, Rybakowski J, Wciórka J. Psychiatria. Wrocław: Urban\&Partner; 2003.

11. Gałecki P, Bobińska K, Eichstaedt K. Ustawa o ochronie zdrowia psychicznego. Komentarz. Warszawa: LexisNexis; 2012.

12. Ustawa z dnia 6 czerwca 1997 roku Kodeks karny (Dz.U.1997. Nr 88 poz. $553 \mathrm{z}$ późn. zm).

13. Krakowska D. Prawo ochrony zdrowia w pytaniach i odpowiedziach prawa pacjenta. Warszawa: Wolters Kluwer; 2008.

\section{Corresponding author}

Tomasz Kucmin

16 Staszica Str., 20-081 Lublin

E-mail: tkucmin@tlen.pl 